\section{Challenges of Establishing Native versus Exotic Status of Herbarium Specimens}

\author{
Andrzej K. Noyszewski ${ }^{1}$, Neil O. Anderson ${ }^{1}$, Alan G. Smith ${ }^{1}$, \\ Andrzej Kilian ${ }^{2}$, Diana Dalbotten ${ }^{3}$, Emi Ito $^{4}$, Anne Timm $^{5}$, \\ and Holly Pellerin ${ }^{6}$
}

\begin{abstract}
Additional Index words. DArTSeqLD, DNA based identification, invasive species, Phalaris arundinacea

SuMMARY. In cases where invasive species are presumed to be strictly exotic, the discovery that the species is also native can be disconcerting for researchers and land managers responsible for eradicating an exotic invasive. Such is the case with reed canarygrass (Phalaris arundinacea), for which decades of misinformation led to the call for nationwide control of this species in the United States. However, native populations were first reported by LaVoie and then later confirmed by Casler with molecular analyses. This, coupled with the discovery by Anderson that this species has been used in weavings by Native Americans for centuries, also made the native forms of interest for protection. Identifying the native status of historic, herbarium specimens via molecular analyses is of great interest to determine localities of native populations for confirmation with extant specimens. Genetic-based methods describing DNA polymorphism of reed canary grass are not well developed. The goal of the presented research is to assess the utility of genomic DNA obtained from historic (herbaria) and extant (fresh) tissue of reed canarygrass and the application of using Diversity Arrays Technology sequencing low density for genetic population studies.
\end{abstract}

$\mathrm{R}$ eed canarygrass is native to Eurasia and North America (Lavergne and Molofsky, 2004); it is a perennial, wind-pollinated, wetland grass, cultivated in temperate regions around the globe for a forage, bioremediation, ornamental use, and biofuel (Olsen and Chong, 1991; Sheaffer et al., 2008). Unfortunately, reed canarygrass is one of the worst invasive species in North American wetlands. In Wisconsin, it dominates $\approx 11 \%$ of wetlands, and in Minnesota, Washington, and Quebec, reed canarygrass is the dominant species on $50 \%$ to $100 \%$ of wetland areas, greatly inhibiting native flora and fauna (Bernthal and Willis, 2004; Galatowitsch et al., 1999; Kercher and Zedler, 2004; Lavergne and Molofsky, 2007). In central Europe, reed canarygrass is a common species and is as aggressive as North American types. However, European researchers do not consider it as invasive (N.O. Anderson, unpublished data). The earliest report of reed canarygrass cultivation as a forage grass is from 1749 (Sweden) with seed source from its native European stands (Alway, 1931; Schoth, 1938). Also, early cultivated reed canarygrass in North America was obtained from native stands. European cultivars of reed canarygrass were repeatedly introduced to North America for forage, beginning in the early 1924 (Alway, 1931).

Before and during European American settlements, numerous $\mathrm{Na}$ tive American tribes in temperate regions across the continent used maygrass $[P$. arundinacea (Densmore, 1974)] to weave mats for storing and drying roots/berries, baskets, peaked hats, fishing weirs, or wigwam (a.k.a. wickiup, wetu) roofs (Kindscher and Noguera, 2002; Turner et al., 1980). In northwestern Minnesota, leaves of nonflowering reed canarygrass plants were harvested along trails or rivers, and leaves were steamed, dried, and bundled until woven (Steltzer, 1976).

Morphological differences that distinguish native and exotic forms of reed canarygrass have not been identified. Various strategies to control, contain, or eradicate reed canarygrass have been employed to manage invasions (Adams and Galatowitsch, 2006). However, the lack of success may be partially due to a lack of understanding of its native vs. exotic status.

\section{Current genetic studies on reed canarygrass}

Reed canarygrass is primarily allotetrapolid $(2 n=4 x=28$; Lavergne and Molofsky, 2004) with the genome size estimated to be $\approx 5 \mathrm{Gbp} / \mathrm{C}$ (Akiyama et al., 2015) wherein $\mathrm{C}$ denotes the amount of DNA contained within a haploid (a single set of unpaired chromosomes) genome of an organism. The most recent molecular genetic analyses of herbaria specimens with use of simple sequence repeat (SSR) markers, compared with extant European types, have confirmed the existence of native North American reed canarygrass populations that existed in North America pre-1940 and are possibly present today (Jakubowski et al., 2011, 2013, 2014). Use of genetic and genomic tools to aid in identifying and controlling invasive species has become increasingly important, allowing the identification of mechanisms directly involved in biological invasions (Harvey-Samuel et al., 2017; Rodrigues et al., 2017; Stewart et al., 2009). DNA-based identification of invasive species is proposed as the federal law and basis of rapid-response management in Canada (Thomas et al., 2016). Sequencing and subsequent detection of single nucleotide polymorphisms (SNPs) and genome-based methods have become more suitable for nonmodel organisms (Ekblom and Galindo, 2011 ; Fitzpatrick et al., 2016) such as reed canarygrass and used within the context of biological invasions and climate change (Chown et al., 2014). DNA-based approaches are necessary, particularly in species where exotic and native forms are morphologically indistinguishable (as in the case of reed canarygrass), making this the

\begin{tabular}{llll}
\hline $\begin{array}{l}\text { Units } \\
\begin{array}{l}\text { To convert U.S. to SI, } \\
\text { multiply by }\end{array}\end{array}$ & U.S. unit & SI unit & $\begin{array}{l}\text { To convert SI to U.S., } \\
\text { multiply by }\end{array}$ \\
\hline 29,574 & $\mathrm{fl} \mathrm{oz}$ & $\mu \mathrm{L}$ & $3.3814 \times 10^{-5}$ \\
2.54 & $\mathrm{inch}(\mathrm{es})$ & $\mathrm{cm}$ & 0.3937 \\
28,350 & $\mathrm{oz}$ & $\mathrm{mg}$ & $3.5274 \times 10^{-5}$ \\
1 & $\mathrm{ppm}$ & $\mathrm{ng} \cdot \mu \mathrm{L}^{-1}$ & 1 \\
$\left({ }^{\circ} \mathrm{F}-32\right) \div 1.8$ & ${ }^{\circ} \mathrm{F}$ & ${ }^{\circ} \mathrm{C}$ & $\left({ }^{\circ} \mathrm{C} \times 1.8\right)+32$
\end{tabular}


only method available to differentiate between both types. Nelson et al. (2014) determined that the population genetic structure of wild, forage, and ornamental exotic and North American Phalaris species harbored a high amount of genetic diversity within, as opposed to among, populations. Thus, range expansion of reed canarygrass in North America is a not result of hybridization among exotic, forage, and native types (Jakubowski et al., 2011) despite previous theories to that effect (Lavergne and Molofsky, 2007).

\section{Use of Diversity Arrays Technology sequencing (DArTseq) in search for DNA polymorphism}

Diversity Arrays Technology sequencing is a highly optimized method

Received for publication 12 Feb. 2018. Accepted for publication 29 Apr. 2019.

Published online 27 August 2019.

${ }^{1}$ Department of Horticultural Science, University of Minnesota, Saint Paul, MN 55108

${ }^{2}$ Diversity Arrays Technology, University of Canberra, Bruce, ACT 2617, Australia

${ }^{3}$ St. Anthony Falls Laboratory, University of Minnesota, Minneapolis, MN 55414

${ }^{4}$ Department of Earth Sciences, University of Minnesota, Minneapolis, MN 55455

${ }^{5}$ Urban Forests, Human Health, and Environmental Quality, U.S. Department of Agriculture, Forest Service, Northern Research Station, Baltimore, MD 21228

${ }^{6}$ St. Anthony Falls Laboratory, University of Minnesota, Minneapolis, MN 55414; and Fond du Lac Tribal and Community College, Cloquet, MN 55720

The Minnesota Invasive Terrestrial Plants and Pests Center (MITPPC), through the Minnesota Environment and Natural Resources Trust Fund of the Legislative Citizens Commission, provided funding for Minnesota Resources. We thank Kaylie Niedzwiecki for help in laboratory work.

This paper was part of the Invasive Plants Research Professional Interest Group workshops "Strategies for Mitigating Invasiveness of Native Species," held on 30 Sept. 2017 in Waikoloa, HI, and "It's Native. Wait! It's Exotic ... Oh No, It's a Nuisance!" held on 3 Aug. 2018 in Washington, DC.

A.K.N. is a Postdoctoral Research Associate.

N.O.A. and A.G.S. are Professors

A.K. is a Director.

D.D. is an Associate Director of Diversity and Broader Impacts.

E.I. is a Professor and Director of the Limnological Research Center.

A.T. is a Research Aquatic Ecologist, Urban Forests, Human Health, and Environmental Quality.

H.P. is a Research Scientist, Elder, and Instructor.

N.O.A. is the corresponding author. E-mail: ander044@ umn.edu.

This is an open access article distributed under the CC BY-NC-ND license (https://creativecommons.org/ licenses/by-nc-nd/4.0/).

https://doi.org/10.21273/HORTTECH04313-19 of targeted DNA-based identification by detecting SNPs of studied samples. DArTseqLD is a variation of the original method developed by Diversity Arrays Technology (Bruce, Australia) that offers lower density of markers, thus lowering the cost of analysis compared with traditional DArTseq. The DArTseqLD method allows whole genome SNP analysis with wide genome representation. Despite its lower density, DArTseqLD is capable of delivering up to at least 10,000 markers per analyzed line (Diversity Arrays Technology, 2019) and is a useful DNA polymorphism identification method in species for which genomic tools are not well developed. This method is highly suitable for nonmodel species, such as many species recognized as being invasive and weedy. Diversity Arrays Technology provides a cost- and labor-efficient platform for projects that want to develop a reliable DNA polymorphism identification system for their species (Fig. 1). In addition, the dartR software package was developed that allows for efficient conversion and support of molecular marker data analysis delivered by DArTseqLD technology within $\mathrm{R}$ programming language (Gruber et al., 2018).

The goal of this pilot experiment was to assess the utility of genomic DNA (gDNA) obtained from historic (herbaria) and extant (fresh) tissue of reed canarygrass and the application of using DArTseqLD for genetic population studies. This is a new molecular technology approach for use with reed canarygrass. Previous research used inter-SSRs [ISSRs (Anderson et al., 2016; Kávová et al., 2018)], SSRs (Anderson et al., 2018; Jakubowski et al., 2014), or expressed sequence tag (EST)-SSR markers (Barth et al., 2016). This preliminary research was necessary for trouble-shooting methodology before performing full-scale reed canarygrass population structure analyses to distinguish between native and exotic reed canarygrass in our core collection of samples. Our collection of reed canarygrass consists of Minnesota, Czech Republic, and Lithuania wild populations and Minnesota, North Dakota, and Iowa herbarium specimens and selection of cultivars.

\section{Material and methods}

Historic (herbaria) reed canarygrass tissue for the pilot experiment was collected from the University of Minnesota Herbarium (Bell Museum of Natural History, St. Paul, MN). A sampling of the reed canarygrass herbarium collection was selected to represent the earliest possible native collections in Minnesota (before 1940). Destructive sampling of $\approx 1 \times 0.25$ inch of preserved (dry) mature leaf tissue was performed on each sample using the least visible areas of a leaf to preserve the original specimen's visual integrity and maintain their value as type specimens. In addition to herbarium collection, a small sampling of extant (fresh) leaf samples from wild populations in Minnesota, the Czech Republic (Kávová et al., 2018), and a selection of forage cultivars and the ornamental cultivar Picta also were used. Approximately 6 inches of fresh, mature reed canarygrass leaf tissue per specimen was collected, frozen $\left(-4^{\circ} \mathrm{C}\right)$ and stored $\left(-80{ }^{\circ} \mathrm{C}\right)$. Total gDNA was extracted from $\approx 50 \mathrm{mg}$ of leaf tissue using the DNA extraction kit (Synergy 2.0 Plant DNA Extraction Kit or the 96 Well Synergy Plant DNA Extraction Kit; OPS Diagnostics Laboratory, Lebanon,

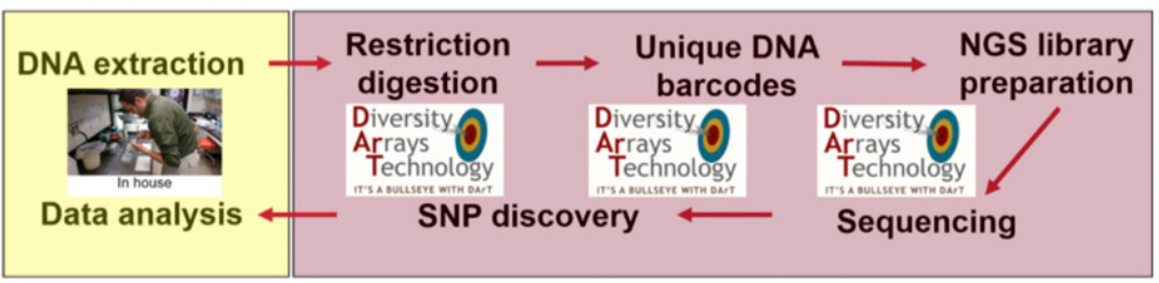

Fig. 1. Overview of DNA polymorphism identification workflow using the Diversity Arrays Technology (Bruce, Australia) sequencing low-density (DArTseqLD) technology. A major advantage of DArTseqLD over other single nucleotide polymorphism (SNP)-based methods of DNA polymorphism identification is the direct delivery of results (marker scoring table) that are suitable to other downstream analysis, such as genetic populations structure analysis. Next-generation sequencing (NGS) is a general term for modern sequencing technologies. 
NJ) with small modifications to the manufacturer's protocol. Both kits have the same extraction buffers; the only difference between them is a single tube extraction vs. a 96-well plate format, respectively. Leaf tissues were kept on ice before processing the samples. Scissors and forceps used for tissue handling were cleaned in soapy water, rinsed twice in water, and dried before cutting each sample. Tissue was ground for $15 \mathrm{~min}$ at $1500 \mathrm{rpm}$ using a homogenizer (Geno/ Grinder; SPEX SamplePrep, Metuchen,

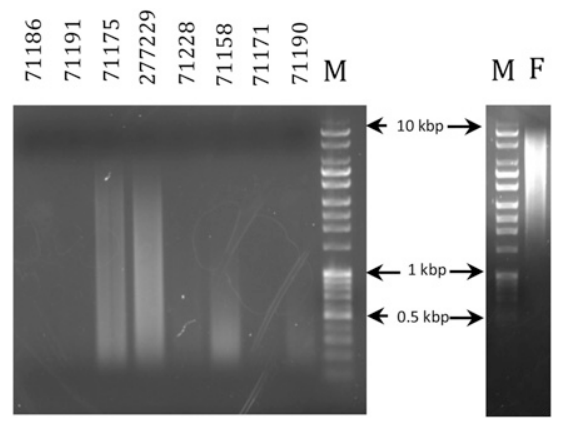

Fig. 2. Gel electrophoresis of reed canarygrass genomic DNA extracted from eight historic (herbaria) samples (identification nos. 71186, 71191*, $71175^{*}, 277229,71228,71158$, $71171,71190)$ compared with extant [fresh (F)] tissue genomic DNA of 'Picta', showing high and variable levels of genomic DNA degradation in the herbaria samples; $M=$ DNA ladder. * Samples previously used by Jakubowski et al. (2013).
NJ). Purified gDNA was suspended in molecular grade water and kept at $-20{ }^{\circ} \mathrm{C}$. DNA quality and quantity was checked with the use of a spectrophotometer (NanoDrop 2000; Thermo Scientific, Waltham, MA).

To test the suitability of reed canarygrass gDNA, polymorphic chain reaction (PCR) amplification was performed using EST-SSRs markers that were previously used to evaluate DNA polymorphism of the fresh tissue collection reed canarygrass (Barth et al., 2016) and internal transcribed spacer (ITS) region used commonly for species identification (Cheng et al., 2015). The same amplification parameters for EST-SSR and ITS regions as suggested by Barth et al. (2016) and Cheng et al. (2015) were used, respectively. For PCR amplification, $1 \mu \mathrm{L}\left(20 \mathrm{ng} \cdot \mu \mathrm{L}^{-1}\right)$ of a DNA template was used with 10 $\mu \mathrm{M}$ of each primer in PCR master mix (GoTaq Green Master Mix, M712; Promega, Madison, WI). Amplification template for PCR was sample no. 71175 and for the control, we used fresh tissue of 'Picta'. The PCR products and gDNA of reed canarygrass were checked on a $1 \%(\mathrm{w} / \mathrm{v})$ agarose gel $(1 \times$ Tris-acetate-EDTA buffer $)$ with ethidium bromide and DNA ladder (HighRanger Plus 100bp; Norgene Biotek Corp, Thorold, ON, Canada). The reed canarygrass samples (20 $n g \cdot \mu \mathrm{L}^{-1}$ of each sample) were submitted to Diversity Arrays Technologies for DNA polymorphism identification.

\section{Results and discussion}

H E R B A R I U M G D N A AMPLification. New molecular marker development and its use depend on the quality of obtained gDNA (Miller et al., 2002; Wandeler et al., 2007). Herbarium samples that are preserved and stored in classic herbaria environments maintain the plant tissue appearance and overall specimen condition to minimize degradation. However, this does not maintain gDNA integrity (Fig. 2). Thus, it is expected that gDNA obtained from herbarium samples may be degraded at some level. The level of sample degradation was assessed on the agarose gel (Fig. 2). Overall, although it was possible to extract gDNA from herbarium specimens, high and variable levels of gDNA degradation were observed. The level of gDNA degradation should not affect DNA polymorphism identification as long as full allelic representation of a species is preserved. However, allele dropout can occur, particularly in the case of herbarium tissue samples, compromising the accuracy of obtained data (Miller et al., 2002; Wandeler et al., 2007).

To test the suitability of herbarium gDNA for DNA polymorphism identification, we used a set of ESTSSR markers that were previously used to assess reed canarygrass populations (Barth et al., 2016). Amplification of molecular markers was possible and the results were consistent (Fig. 3). No differences in amplification were

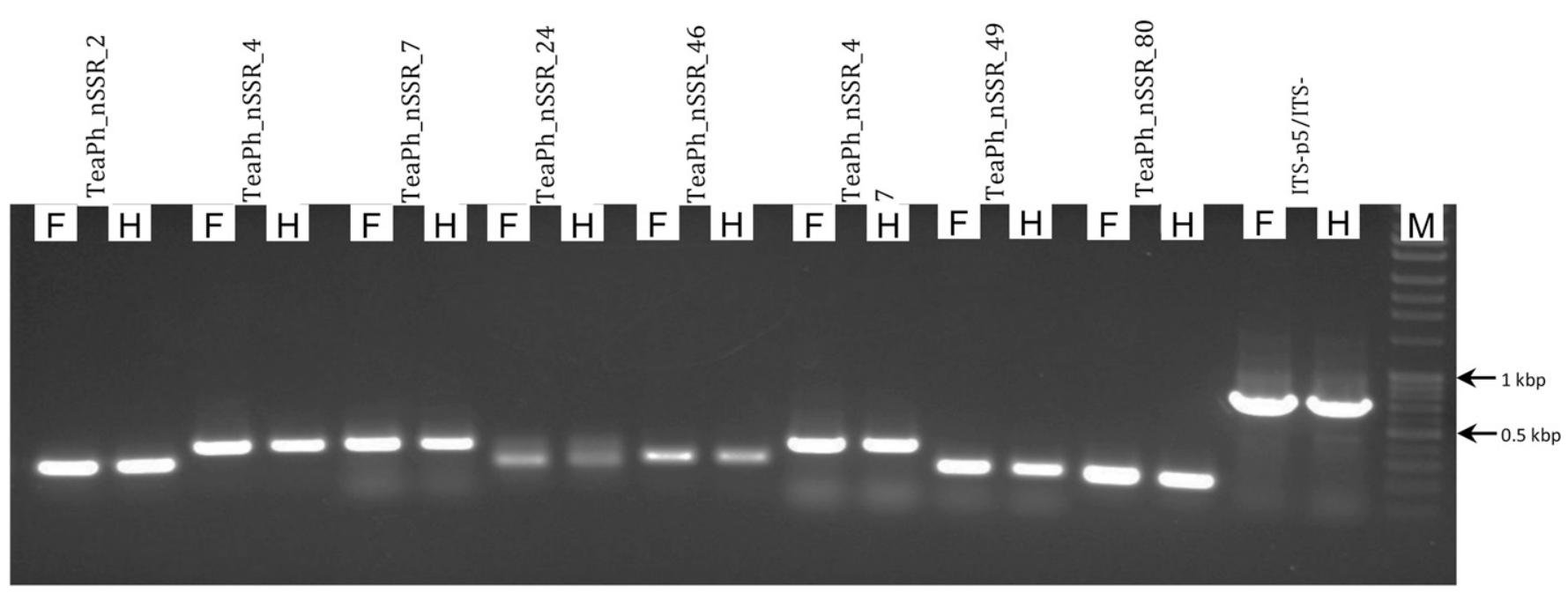

Fig. 3. Amplification of historic (herbaria) genomic DNA from reed canarygrass using selected expressed sequence tag simple sequence repeat [EST-SSR (Barth et al., 2016)] and internal transcribed spacer (ITS) region (Cheng et al., 2015) to test whether the genomic DNA will properly template for downstream applications, such as molecular marker amplification. Markers showed no differences in amplification between extant [fresh $(F)]$ and historic $[$ herbaria $(H)]$ samples; $M=D N A$ ladder. 
observed between gDNA from herbarium $(\mathrm{H})$ and fresh tissue $(\mathrm{F})$. Two markers, TeaPh_nSSR_24 and TeaPh_ nSSR_47, showed weaker PCR bands compared with other markers. However, these results are most likely related to slight differences of annealing temperature that should be used for those two primer sets because both herbarium and fresh tissue gDNA results are similar. Additionally, amplification of the ITS region, which is commonly used for species barcoding, was performed, and the proper size bands for ITS were observed for tissue types (Cheng et al., 2015). Amplification of the ITS region indicates its possible future use for barcoding of herbarium specimens of reed canarygrass and its close relatives. Proper amplification of multiple EST-SSR markers indicated that herbarium gDNA will be suitable for the DArTseqLD method of SNP detection and genetic populations studies.

Genetic DIVERSITY OF PILOT SAMPLES. DArTseqLD proved to be highly successful in development of polymorphic genetic markers for reed canarygrass pilot samples. The analysis identified 16,902 polymorphic SNP markers with an average reference and SNP coverage of $20 \times$ and $14 \times$, respectively, with minimum coverage of $5 \times$. Thus, future analyses of the full data set of extensive reed canarygrass samples in our collection from Minnesota, the Czech Republic, and elsewhere will be useful to identify individuals and populations that are native to Minnesota or Europe, allowing for future identification of native vs. exotic types of reed canarygrass in Minnesota.

\section{Conclusions}

Herbarium samples should be suitable for use in genetic populations studies and could serve as the reference point to establish native vs. exotic status of extant reed canarygrass types. DArTseqLD produced a high number $(>16,000)$ of polymorphic SNP markers for the pilot experiment. Current results provide a starting point to describe fully our extensive reed canarygrass collection (Minnesota and Czech rivers, cultivars, and herbaria specimens) in search for native and exotic types in Minnesota with the use of DArTseqLD technology. Future research will elucidate the role of native vs. exotic types in relation to reed canarygrass invasive potential in Minnesota and/or North America and facilitate discovery of genomic regions that are specific for native North American vs. exotic European types.

\section{Literature cited}

Adams, C. and S.M. Galatowitsch. 2006. Increasing the effectiveness of reed canary grass (Phalaris arundinacea L.) control in wet meadow restorations. Restor. Ecol. $14: 441-451$.

Alway, F. 1931. Early trials and use of reed canary grass as a forage plant. J. Amer. Soc. Agron. 23:64-66.

Akiyama, Y., K. Kimura, A. Kubota, M. Fujimori, H. Yamada-Akiyama, Y. Takahara, and Y. Ueyama. 2015. Comparison of genome size in reed canarygrass (Phalaris arundinacea $\mathrm{L}$.) exotic and putative native Japanese genotypes by flow cytometry. Jpn. Agr. Res. Qrtly. 49:345-350.

Anderson, N.O., T. Kávová, D. Bastlová, V. Čurn, B. Kubátová, K.R. Edwards, V. Januš, and J. Květ. 2016. Phenotypic and genotypic variation in Czech forage, ornamental and wild populations of reed canarygrass. Crop Sci. 56:2421-2435.

Anderson, N.O., L. Jociene, E. Krokaitė, T. Rekašius, A. Paulauskas, and E. Kupčinskienè. 2018. Genetic diversity of Phalaris arundinacea populations in relation to river regulation in the Merkys Basin, Lithuania. River Res. Appl. 34:300-309.

Barth, S., M.J. Jankowska, T.R. Hodkinson, T. Vellani, and M. Klaas. 2016. Variation in sequences containing microsatellite motifs in the perennial biomass and forage grass, Phalaris arundinacea (Poaceae). BMC Res. Notes 9:184-188.

Bernthal, T.W. and K.G. Willis. 2004. Using LANDSAT 7 imaginary to map invasive reed canary grass (Phalaris arundinacea): A landscape level wetland monitoring methodology. Wisconsin Dept. Natural Resources PUB-SS-992.

Cheng, T., X. Chao, L. Lei, C. Li, Y. Zhang, and S. Zhou. 2015. Barcoding the kingdom Plantae: New PCR primers for ITS regions of plants with improved universality and specificity. Mol. Ecol. Resour. 16:138-149.

Chown, S.L., K.A. Hodgins, P.C. Griffin, J.G. Oakeshott, M. Byrne, and A.A. Hoffmann. 2014. Biological invasions, climate change and genomics. Evol. Appl. $8: 23-46$.

Densmore, F. 1974. How Indians use wild plants for food, medicine, and crafts. Courier Dover Publications, Mineola, NY.
Diversity Arrays Technology. 2019. Welcome to Diversity Arrays Technology. 17 Jan. 2019. <https://www.diversityarrays. $\mathrm{com} />$.

Ekblom, R. and J. Galindo. 2011. Applications of next generating sequencing in molecular ecology of non-model organisms. Heredity 107:1-15.

Fitzpatrick, M.A., E.A. Ozer, and A.R. Hauser. 2016. Utility of whole-genome sequencing in characterizing acinetobacter epidemiology and analyzing hospital outbreaks. J. Clin. Microbiol. 54:593-612.

Galatowitsch, S.M., N.O. Anderson, and P. Ascher. 1999. Invasiveness in wetland plants in temperate North America. Wetlands 19:733-755.

Gruber, B., P.J. Unmack, O.F. Berry, and A. Georges. 2018. dartr: An r package to facilitate analysis of SNP data generated from reduced representation genome sequencing. Mol. Ecol. Resour. 18:691699.

Harvey-Samuel, T., T. Ant, and L. Alphey. 2017. Towards the genetic control of invasive species. Biol. Invasions 19:1683-1703.

Jakubowski, A.R., M.D. Casler, and R.D. Jackson. 2011. Has selection for improved agronomic traits made reed canarygrass invasive? PLoS One 6:e25757.

Jakubowski, A.R., M.D. Casler, and R.D. Jackson. 2013. Genetic evidence suggests a widespread distribution of native North American populations of reed canarygrass. Biol. Invasions 15:261-268.

Jakubowski, A.R., M.D. Casler, and R.D. Jackson. 2014. The history of reed canarygrass in North America: Persistence of natives among invading Eurasian populations. Crop Sci. 54:210-219.

Kávová, T., B. Kubátová, V. Čurn, and N.O. Anderson. 2018. Genetic variability of US and Czech Phalaris arundinacea L. wild and cultivated populations, p. 1-19. In: New perspectives in forage crops. IntechOpen, London, UK.

Kercher, S.M. and J.B. Zedler. 2004. Multiple disturbances accelerate invasion of reed canary grass (Phalaris arundinacea L.) in a mesocosm study. Oecologia 138:455-464.

Kindscher, K. and E. Noguera. 2002. Cultural use of plants from the Baker Wetlands. Kansas Biol. Survey, Univ. Kansas, Lawrence.

Lavergne, S. and J. Molofsky. 2004. Reed canary grass (Phalaris arundinacea) as a biological model in the study of plant invasions. Crit. Rev. Plant Sci. 23:415429. 
Lavergne, S. and J. Molofsky. 2007. Increased genetic variation and evolutionary potential drive the success of an invasive grass. Proc. Natl. Acad. Sci. USA 104:3883-3888.

Miller, C.R., P. Joyce, and L.P. Waits. 2002. Assessing allelic dropout and genotype reliability using maximum likelihood. Genetics 160:357-366.

Nelson, M.F., N.O. Anderson, M.D. Casler, and A.R. Jakubowski. 2014. Population genetic structure of N. American and European Phalaris arundinacea L. as inferred from inter-simple sequence repeat markers. Biol. Invasions 16:353363.
Olsen, F.J. and S.K. Chong. 1991. Reclamation of acid coal refuse. Landsc. Urban Plan. 20:309-313.

Rodrigues, T.B., R.K. Dhandapani, J.J. Duan, and S.R. Palli. 2017. RNA interference in the Asian longhorned beetle: Identification of key RNAi genes and reference genes for RT-qPCR. Sci. Rpt. 7:8913.

Schoth, H.A. 1938. Reed canary grass. U.S. Dept. Agr. Farmers' Bul. No. 1602.

Sheaffer, C.C., C.J. Rosen, and S.C. Gupta. 2008. Reed canarygrass forage yield and nutrient uptake on a year-round wastewater application site. J. Agron. Crop Sci. 194:465-469.

Steltzer, U. 1976. Indian artists at work. Univ. Washington Press, Seattle, WA.

Stewart, C.N., Jr., P.J. Tranel, D.P. Horvath, J.V. Anderson, L.H. Rieseberg,
J.H. Westwood, C.A. Mallory-Smith, M.I. Zapiola, and K.N. Dlugosch. 2009. Evolution of weediness and invasiveness: Charting the course for weed genomics. Weed Sci. 57:451-462.

Thomas, V.G., R.H. Hanner, and A.V. Borisenko. 2016. DNA-based identification of invasive alien species in relation to Canadian federal policy and law, and the basis of rapid-response management. Genome 59:1023-1031.

Turner, N.J., R. Bouchard, and D.I.D. Kennedy. 1980. Ethnobotany of the Okanagan-Colville Indians of British Columbia and Washington. British Columbia Provincial Museum, Victoria, BC, Canada.

Wandeler, P., P.E.A. Hoeck, and L.F. Keller. 2007. Back to the future: Museum specimens in population genetics. Trends Ecol. Evol. 22:634-642. 